\title{
JURNAL
}

\section{PERBANDINGAN ANTARA METODE ICE BREAKING DENGAN COMPARASI TERHADAP MOTIVASI BELAJAR SISWA KELAS III DI MI AL-KHAIRIYAH SINAR BATEN TALANGPADANG}

Disusun Untuk Memenuhi Syarat Menyelesaikan Program Strata 1 (S1)

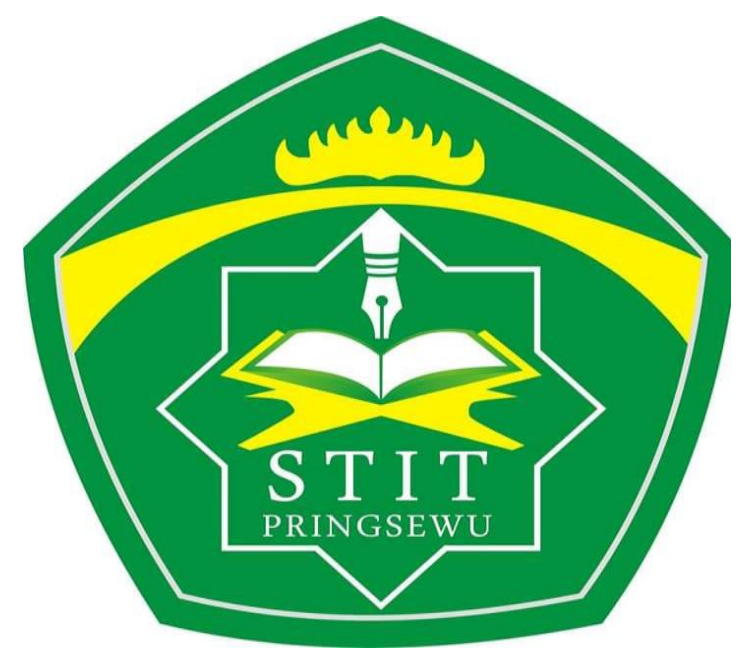

Disusun Oleh :

Rexsa Habsah

15020025

PROGRAM STUDI PENDIDIKAN GURU MADRASAH IBTIDAIYAH (PGMI)

SEKOLAH TINGGI ILMU TARBIYAH (STIT)

PRINGSEWU-LAMPUNG

TAHUN PELAJARAN 2019/2020 


\title{
PERBANDINGAN ANTARA METODE ICE BREAKING DENGAN COMPARASI TERHADAP MOTIVASI BELAJAR SISWA KELAS III DI MI AL-KHAIRIYAH SINAR BATEN TALANGPADANG
}

\author{
Rexsa Habsah $^{1}$, Muhtarom,M.Sc. ${ }^{2}$ \\ STIT PRINGSEWU \\ Jalan Raya Wonokriyo, Gading Rejo, Pringsewu, Lampung 35373 Telp 0729333091 \\ E-mail : ${ }^{1}$ RexsaHabsah27@gmail.com , ${ }^{2}$ mutharom29@gmail.com
}

\begin{abstract}
This study aims to determine the effect of ice breaking use on student motivation and find out the comparison between the ice breaking method with the comparison of learning motivation in class III MI Al-khairiyah Sinar Banten Talangpadang students. The research method used is a quantitative method and the sample in this study was class III A and class III B MI Al-Khairiyah Sinar Banten which was divided into two, namely the experimental class and the control class. The total number of samples of this study were 68 students, consisting of 34 experimental class students and 34 control classes. Instrument The type of research used is one sample research $t$ test consisting of the experimental class and the control class, with the experimental class of the research used is motivation learning questionnaire and observation of learning motivation. The giving of learning motivation questionnaire after giving treatment then the acquisition of value will be compared with the class without giving (control) the results are tested through one sample $t$ test. From the calculation results, the average value of the experimental class is 44.12 and the control class is 29.45 with the sig experimental class 0,000 and the control class $0.05, \mathrm{H} 0$ is rejected and $\mathrm{Ha}$ is accepted. It can be concluded that there is the influence of the application of the ice breaking method when learning takes place to increase the learning motivation of class III students of MI Al-Khairiyah Sinar Banten Talangpadang.
\end{abstract}

Keywords: Ice Breaking, Increased Motivation To Learn

\begin{abstract}
Abstrak
Penelitian ini bertujuan untuk mengetahui pengaruh penggunaan ice breaking terhadap motivasi belajar siswa dan mengetahui perbandingan antara metode ice breaking dengan comparasi terhadap motivasi belajar pada siswa kelas III MI Al-khairiyah Sinar Banten Talangpadang. Metode penelitian yang digunakan adalah metode kuantitatif dan sampel dalam penelitian ini adalah siswa kelas III A dan kelas III B MI Al-Khairiyah Sinar Banten yang terbagi menjadi dua, yaitu kelas eksperimen dan kelas kontrol. Jumlah total sampel penelitian ini adalah 68 siswa, yang terdiri dari 34 siswa kelas eksperimen dan 34 kelas kontrol. Instrument Jenis penelitian yang digunakan adalah penelitian one sampel t test yang terdiri dari kelas eksperimen dan kelas kontrol, dengan kelas eksperimen penelitian yang digunakan adalah angket motivasi belajar dan observasi motivasi belajar. Pemberian angket motivasi belajar sesudah memberikan perlakuan senlanjutnya perolehan nilai akan dibandingkan dengan kelas yang tanpa pemberian (kontrol) hasilnya diuji melalui one sampel $t$ test. Dari hasil perhitungan diperoleh nilai rata-rata hitung kelas eksperimen sebesar 44,12 dan kelas kontrol sebesar 29,45 dengan sig kelas eksperimen 0,000 dan kelas kontrol 0,05 maka $\mathrm{H}_{0}$ ditolak dan $\mathrm{H}_{\mathrm{a}}$ diterima. Dapat disimpulkan ada pengaruh penerapan metode ice breaking saat pembelajaran berlangsung terhadap peningkatan motivasi belajar siswa kelas III MI Al-Khairiyah Sinar Banten Talangpadang.
\end{abstract}

Kata-Kata Kunci: Ice Breaker, Motivasi Belajar 


\section{PENDAHULUAN}

Pendidikan merupakan proses perubahan sikap dan tingkah laku seseorang atau kelompok orang dalam usaha mendewasakan manusia melalui upaya pengajaran, pelatihan, proses, cara, dan perbuatan mendidik. Pendidikan merupakan suatu kebutuhan yang mutlak harus didapatkan sebagai tonggak awal majunya sebuah Negara dan setiap manusia berhak untuk mendapatkan pendidikan.

Keberhasilan suatu pendidikan salah satunya ditentukan oleh motivasi, dalam proses belajar mengajar motivasi sebagi penggerak didalam diri siswa yang bergun ameningkatkan usaha dan dorongan untuk belajar.

Proses pembelajaran akan berhasil apabila siswa mempunyai motivasi dalam belajar. Menrut Hamzah B. Uno (2013: 31) terdapat beberapa indicator yang berperan dalam mengetahui motivasi belajar siswa, yaitu: (1) adanya hasrat atau keinginan untuk berhasil, (2) adanya dorongan dan kebutuhan dalam belajar, (3) adanya penghargaan dalam belajar, (4) adanya harapan dan cita-cita dimasadepan, (5) adanya kegiatan belajar yang menarik, dan (6) adanya lingkungan belajar yang kondusif, sehingga memungkinkan seorang pesertadidik dapat belajar dengan baik.

Siswa yang mempunyai motivasi belajar tinngi, akan melakukan aktifitas belajar dengan baik. Sedang kan siswa yang tidak mempunyai motivasi belajar tidak akan melakukan aktivitas belajar dengan baik, tampak acuh tak acuh, suka mengganggu teman dalam kelas, mudah putus asa dan perhatiannya tidak tertuju pada pelajaran sehingga berakibat pada rendahnya prestasi belajar siswa. Hal ini dapat dilihat dari cirri-ciri siswa pada saat proses pembelajaran berlangsung.

Pada dasarnya guru dituntun untuk menciptakan sebuah pembelajaran yang efektif dengan menetapkan metode atau strategi pembelajaran yang akan digunakan saat proses pembelajaran berlangsung, sehingga proses pembelajaran tidak membosankan dan siswa dituntut untuk berprestasi yakni dengan adanya dorongan semangat belajar dari guru dalam memperoleh pembelajaran. Menurut Adi Wira Gunawan (2003: 154) dalam buku"Genius Learning Strategy" menyatakan sesungguhnya tidak ada pelajaran yang membosankan, yang ada adalah guru yang membosankan, karena tidak mengerti cara menyajiakan materi dengan benar, menyenangkan, dan menarik minat serta perhatian siswa.
Pemilihan metode dan strategi pembelajaran dikelas untuk menghilangkan kejenuhan siswa adalah dengan memberikan ice breaking. Ice breaking adalah suatu bentuk permainan atau kegiatan yang berfungsi untuk mengubah suasana kebekuan dalam kelas Budiman (2016:79). Ice breaking dalam pembelajaran dapat diartikan sebagai pemecahan situasi kebekuan pikiran sehingga membuat perasaan menjadi senang. Ice breaking digunakan untuk menciptakan suasana belajar dari pasif menjadi aktif, dari kaku menjadi gerak, dan jenuh menjadi riang (Sunarto, 2012: 3).

Berdasarkan hasil obsevasi yang dilakukan peneliti pada saat proses pembelajaran berlangsung pada siswa kelas III di MI Al-khairiyah Sinar Banten Talang padang, diketahui bahwa banyak masalah yang ditemukan yang berkaitan dengan proses pembelajaran misalnya ketika penyampaian materi, guru hanya menjelaskan ulang materi yang ada di dalam buku dan siswa hanya mendengarkan. Terlihat banyak siswa yang tidak fokus, mengobrol, menggambar, dan tertidur. Hal ini sangat membuktikan bahwa motivasi belajar siswa sangat rendah. Pada akhirnya siswa diminta mengerjakan soal, siswa kurang antusias dalam mengerjakan soal karena tidak adanya pujian atau penghargaan dalam keberhasilan mengerja kan soal.

Berdasarkan uraian permasalahan diatas, maka penulis akan melakukan penelitian dengan judul "PERBANDINGAN ANTARA METODE ICE BREAKING DENGAN COMPARASI TERHADAP MOTIVASI BELAJAR SISWA KELAS III DI MI AL-KHAIRIYAH SINAR BATEN TALANGPADANG”. Dengan penerapan metode ice breaking terhadap motivasi siswa kelas III diharapkan mampu menciptakan suasana belajar yang menyenangkan tidak membosankan dan pada akhirnya memiliki pengaruh signifikan terhadap motivasi belajar siswa kelas III di MI Al-Khairiyah Sinar Banten Talangpadang tahun ajaran 2018/2019.

\section{TUJUAN}

Tujuan penelitian ini adalah: (a) Untuk mengetahui peningkatan motivasi belajar dengan penerapan metode ice breaking siswa kelas III di MI Al-Khairiyah Sinar Banten Talangpadang, (b) Untuk mengetahui perbandingan antara metode ice breaking dengan comparasi terhadap motivasi belajar siswa kelas III di MI Al-Khairiyah Sinar Baten Talangpadang 


\section{METODE PENELITIAN}

Penelitian yang akan penulis lakuakan ini adalah penelitian kuantitatif karena data-data yang akan dikumpulkan berbentuk angka dengan proses pengolahan datanya menggunakan instrumen angket dan observasi. Jenis penelitian yang digunakan adalah penelitian one sampel t test, Sugiyono (2015) yang akan dihitung menggunakan program statistical package for the social sciences (SPSS). Objek yang akan diteliti terdiri dari kelas eksperimen dan kelas kontrol, dengan kelas eksperimen menggunakan metode ice breaking dan kelas kontrol tidak menggunakan metode ice breaking.

\section{Waktu dan Tempat Penelitian}

Penelitian ini dilaksanakan di MI AlKhairiyah Sinar Banten yang tepatnya terletak di jln. Abdul Mutholib Kel. Sinar Banten Kec. Talang padang Kab. Tanggamus Prov. Lampung. Kelas III A dan III B, waktu penelitian dilakukan pada semester genap 2018-2019.

\section{Populasi}

Populasi dalam penelitian ini adalah siswa kelas III A dan III B. Adapun jumlah kelas III A yaitu 34 siswa, dan kelas III B berjumlah 34 siswa. Jumlah keseluruhan populasi dalam penelitian ini adalah 68 siswa.

Table 1. Populasi Penelitian

\begin{tabular}{|c|c|c|}
\hline No & Kelas & Jumlah siswa \\
\hline 1 & III A & 34 Siswa \\
\hline 2 & III B & 34 Siswa \\
\hline \multicolumn{2}{|c|}{ Total } & 68 Siswa \\
\hline
\end{tabular}

\section{Sampel Penelitian}

Sampel dalam penelitian ini adalah siswa kelas III A dan III B MI Al-Khairiyah Sinar Banten yang terbagi menjadi dua, yaitu kelas eksperimen dan kelas control. Jumlah total sampel penelitian ini adalah 68 siswa, yang terdiri dari 34 siswa kelas eksperimen dan 34 kelas kontrol.

\section{Teknik Pengumpulan Data}

Menurut Arikunto, Suharsimi. (2010:160) instrument penelitian adalah alat atau fasilitas yang digunakan oleh peneliti dalam mengumpulkan data agar pekerjaan lebih mudah dan hasil nya baik, dalam artian lebih cermat, lengkap dan sistematis sehingga data lebih mudah diolah, adapun istrumen yang digunakan dalam penelitian ini adalah sebagi berikut: 1) Angket yang digunakan berupa angket tertutup yang telah dilengkapi jawaban yang dapat dipilih responden. Angket ini menggunakan sekala likert yang digunakan untuk mengukur sekala motivasi siswa dalam proses pembelajar. Dari lembar angket respon siswa terhaap motivasi belajar dapat diketahui dari hasil penerapan ice breaking siswa kelas III di MI Al-Khairiyah Sinar Banten Talangpadang. 2) Observasi yaitu dilakukan obsevasi oleh observer terhadap aktivitas guu dan siswa dalam proses pembelajaran, observasi ini menggunakan instrument berupa check-list yang digunakan untuk mengamati aktivitas belajar siswa dan kegiatan mengajar yang dilakukan oleh guru pada saat dikelas. Kategori skor ini adalah: sering sekali, sering, kadang-kadang, jarang dan jarang sekali.

Table 2. Kategori Skor Angket

\begin{tabular}{|c|l|c|}
\hline No & \multicolumn{1}{|c|}{ Kategori } & Sekor \\
\hline 1 & Sering Sekali & 5 \\
\hline 2 & Sering & 4 \\
\hline 3 & Kadang-kadang & 3 \\
\hline 4 & Jarang & 2 \\
\hline 5 & Jarang Sekali & 1 \\
\hline
\end{tabular}

Penelitian ini terdiri dari tiga tahap yaitu tahap I persiapan, tahap II pelaksanaan, dantahap III akhir penelitian. Hal ini dilakuakan untuk dapat mengungkapkan secara tuntas mengenai permasalahan yang diajukan dalam penelitian ini. 
Data yang dikumpulkan dalam penelitian ini adalah data motivasi belajar siswa. Mengukur motivasi belajar siswa digunakan instrument penelitian berupa kuesioner yang berjumlah 10 butir pertanyaan. Data yang telah diperoleh kemudian dianalisis secara desktiptif dengan mencari rata-rata hitung, median, modus, standar deviasi, variansi, skor maksimum, skor minimum, dan rentang. Teknik analisis data yang digunakan untuk menguji hipotesis dalam penelitian ini menggunakan one sampel t teks.

Berdasarkan angket dari data motivasi belajar siswa tersebut kemudian klasifikasikan pada kriteria sebagai berikut:

Tabel 3. Klasifikasi Tingkat Motivas Siswa

\begin{tabular}{|c|l|c|}
\hline No & \multicolumn{1}{|c|}{ Klasifikasi } & Nilai \\
\hline 1 & Sangat Tinggi & $41-50$ \\
\hline 2 & Tinggi & $31-40$ \\
\hline 3 & Sedang & $21-30$ \\
\hline 4 & Rendah & $11-20$ \\
\hline 5 & Sangat Rendah & $0-10$ \\
\hline
\end{tabular}

Dari tabel diatas dapat disimpulkan bahwa siswa yang memperoleh nilai motivasi 40-50 termasuk dalam klasifikasi sangat tinggi, siswa yang memperoleh nilai motivasi 30-40 termasuk dalam klasifikasi tinggi, siswa yang memperoleh nilai motivasi 20-30 termasuk dalam klasifikasi sedang, siswa yang memperoleh nilai motivasi 10-20 termasuk dalam klasifikasi rendah dan siswa yang memperoleh nilai motivasi $0-10$ termasuk dalam klasifikasi sangat rendah.

\section{HASIL DAN PEMBAHASAN}

Deskripsi data yang disakijan berdasarkan data yang diperoleh dari hasil pengisian angket dan observasi motivasi belajar yang diberikan kepada siswa kelas III A dan III B di MI Al-Khairiyah Sinar Banten Talangpadang yang berjumlah kelas III A 34 siswa dan kelas III B 34 siswa, keseluruhan berjumlah 68 siswa, dalam pengisian angket dan observasi motivasi belajar siswa kelas III A sebagai kelas eksperimen yang menggunakan metode ice breaking dan siswa kelas III B sebagai kelas kontrol yang tidak menggunakan metode ice breaking dengan tujuan untuk melihat peningkatan motivasi belajar siswa dan untuk mengetahui perbandingan antara metode ice breaking dengan comparasi terhadap motivasi belajar siswa kelas III di MI AlKhairiyah Sinar Baten Talangpadang.

Berdasarkan hasil penghitungan manual dan menggunakan program statistical package for the social sciences (SPSS), maka dapat dideskripsikan hasil penelitian sebagai berikut:

Table 4. Deskripsi Data Hasil Angket dan Observasi Motivasi Belajar Siswa

\begin{tabular}{|l|c|c|}
\hline \multicolumn{1}{|c|}{ Data Statistik } & \multicolumn{2}{|c|}{ Motivasi Belajar } \\
\cline { 2 - 3 } & $\begin{array}{c}\text { Kelas } \\
\text { Eksperimen }\end{array}$ & $\begin{array}{c}\text { Kelas } \\
\text { Kontrol }\end{array}$ \\
\hline Rata-rata Hitung & 44,12 & 29,45 \\
\hline Median & 45 & 30 \\
\hline Modus & 45 & 30 \\
\hline Variansi & 9,683 & 59,406 \\
\hline Standar Deviasi & 3,11171 & 7,70750 \\
\hline Skor Maksimum & 50 & 45 \\
\hline Skor Minimum & 39 & 17 \\
\hline Rentangan & 11 & 28 \\
\hline
\end{tabular}

Hasil analisis deskriptip menunjukan bahwa rata-rata hitung data motivasi belajar menggunakan ice breaking yang berjumlah 34 orang adalah 44,12 berdasarkan hal tersebut dinyatakan bahwa rata-rata hitung motivasi belajar kelas eksperimen termasuk klasifikasi sangat tinggi. Sedangkan pada kelas kontrol yang belajar tanpa menggunakan metode ice breaking yang berjumlah 34 orang adalah 29,45 dengan rata-rata hitung motivasi belajar siswa kelas kontrol termasuk klasifikasi sedang.

Median merupakan nilai tengah, nilai median kelas eksperimen 45 sehingga termasuk dalam klasifikasi sangat tinggi, dan median kelas kontrol 30 termasuk dalam klasifikasi sedang. Modus merupakan nilai yang sering muncul, nilai modus kelas eksperimen 45 termasuk dalam klasifikasi sangat tinggi, dan kelas kontrol 30 termasuk dalam klasifikasi sedang. 
Tabel 5. Jumlah Kategori Siswa

\begin{tabular}{|c|l|c|c|}
\hline \multirow{2}{*}{ No } & \multirow{2}{*}{ Kategori } & \multicolumn{2}{|c|}{ Jumlah siswa } \\
\cline { 3 - 4 } & & $\begin{array}{c}\text { Kelas } \\
\text { Eksperimen }\end{array}$ & $\begin{array}{c}\text { Kelas } \\
\text { Kontrol }\end{array}$ \\
\hline 1 & Sangat Tinggi & 30 siswa & 4 siswa \\
\hline 2 & Tinggi & 4 siswa & 11 siswa \\
\hline 3 & Sedang & - & 10 siswa \\
\hline 4 & Rendah & - & 9 siswa \\
\hline 5 & Sangat Rendah & - & - \\
\hline
\end{tabular}

Variansi merupakan ukuran keberagaman data, jika angka valiansi semakin besar maka semakin beragamah data yang kita miliki dan semakin kecil nilai valiansi maka semakin homogen lah data yang kita miliki, variansi kelas eksperimen 9,683 maka valiansinya semakin homogen sedangakan valiansi kelas kontrol 59,406 maka valiansinya semakin beragam.

Setandar deviasi digunakan untuk mengetahui penyimpangan antara data sampel dengan rata-ratanya secara definisi, standar deviasi kelas eksperimen 3,11171 maka standar penyimpangan dengan rata-ratanya semakin kecil sedangkan kelas kontrol 7,70750 maka standar penyimpangan dengan rata-ratanya semakin besar.

Nilai maksimum merupakan nilai terbesar yang harus dicapai dalam peningkatan motivasi belajar aiswa, nilai maksimal kelas eksperimen 50 dan nilai maksimum kelas kontrol 45 jadi dapat disimpulkan nilai tertinggi yang harus dicapai dalam meningkatkan motivasi belajar kelas eksperimen 50 dan kelas kontrol 45.

Nilai minimum merupakan nilai terkecil yang dicapai dalam proses meningkatkan motivasi belajar siswa, nilai minimum kelas eksperimen 39 dan kelas kontrol 17 jadi dapat disimpulkan bahwa yang mendapat kan nilai 39 dan 17 termasuk dalam nilai motivasi yang terkecil. Rentangan merupakan selisih antara kelas eksperimen dan kelas kontrol, rentangan kelas eksperimen 11, kelas kontrol 27 jadi rentangan kelas eksperimen dan kelas kontrol sebesar 16.

Berdasarkan pemaparan diatas terdapat perbandingan yang signifikan yang dapat kita lihat dari nilai rata-rata hitung, median, modus, valiansi, setandar deviasi, niali maksimum, nilai minimum, dan rentangan motivasi belajar siswa. Diketahui bahwa siswa yang belajar menggunakan metode ice breaking lebih baik dari pada siswa yang belajar tanpa menggunakan metode ice breaking. Hal tersebut tercermin dari rata-rata hitung siswa yang proses pembelajaran nya menggunaka metode ice breaking lebih tinggi dari pada siswa yang proses pembelajarannya tanpa menggunakan metode ice breaking.

Table 6. Paired Samples Test 3

\begin{tabular}{|c|c|c|c|c|c|c|c|c|}
\hline & \multicolumn{5}{|c|}{ Paired Differences } & \multirow[b]{3}{*}{$\mathrm{t}$} & \multirow[b]{3}{*}{$\mathrm{df}$} & \multirow{3}{*}{$\begin{array}{c}\text { Sig. } \\
(2- \\
\text { tailed } \\
\text { ) }\end{array}$} \\
\hline & \multirow[b]{2}{*}{$\begin{array}{c}\mathrm{Me} \\
\text { an }\end{array}$} & \multirow{2}{*}{\begin{tabular}{|c|} 
Std. \\
Devia \\
tion
\end{tabular}} & \multirow{2}{*}{$\begin{array}{l}\text { Std. } \\
\text { Error } \\
\text { Mean }\end{array}$} & \multicolumn{2}{|c|}{$\begin{array}{c}95 \% \\
\text { Confidence } \\
\text { Interval of } \\
\text { the } \\
\text { Difference }\end{array}$} & & & \\
\hline & & & & $\begin{array}{c}\text { Lowe } \\
\mathrm{r}\end{array}$ & Upper & & & \\
\hline $\begin{array}{ll}\mathrm{Pa} & \text { eksperi } \\
\text { ir } & \text { men - } \\
1 & \text { control }\end{array}$ & $\begin{array}{r}1.4 \\
676 \\
5 \mathrm{E} 1\end{array}$ & $\begin{array}{r}8.186 \\
17\end{array}$ & $\begin{array}{r}1.403 \\
92\end{array}$ & $\begin{array}{r}11.82 \\
018\end{array}$ & \begin{tabular}{|r|}
17.53 \\
276
\end{tabular} & $\begin{array}{r}10 . \\
454\end{array}$ & 33 & .000 \\
\hline
\end{tabular}

Dari tabel 6. Paired sampel test 3 ini kita dapat melihat apakah ada perbedaan antara kelas eksperimen dan kelas kontrol. Diketahui bahwa nilai sig (2-tailed) sebesar $0,000 \leq 0,05$ hal ini berarti menunjukan bahwa $\mathrm{H}_{0}$ ditolak dan $\mathrm{H}_{\mathrm{a}}$ diterima. Sehingga terdapat perbedaan yang nyata antara kelas yang menggunakan metode ice breaking (eksperimen) dengan kelas yang tidak menggunakan ice breaking (kontrol) . jadi dapat kita simpulkan bahwa dengan menggunakan metode ice breaking dapat meningkatkan motivasi belajar siswa kelas III di MI Al-Khairiyah Sinar Banten Talangpadang.

\section{PENUTUP}

\section{Kesimpulan}

Dari berdasarkan hasil penelitian secara keseluruhan peningkatan motivasi belajar siswa kelas III, ada peningkatan ketika siswa diberikan perlakuan berupa metode ice breaking bisa meningkatkan motivasi belajar siswa kelas III MI Al-Khairiyah Sinar Banten Talangpadang.

Dengan dibuktikan dari hasil perhitungan nilai rata-rata hitung kelas eksperimen 44,12 maka rata-rata hitung ini termasuk kedalam klasifikasi 
sangat tinggi sedangkan kelas kontrol 29,4 maka termasuk kedalam klasifikasi motivasi siswa sedang, dengan tarap signifikan $0,000 \leq 0,05$ hal ini menunjukan bahwa $\mathrm{H}_{0}$ ditolak dan $\mathrm{H}_{\mathrm{a}}$ diterim.

Dalam penelitian ini metode ice breaking merupakan salah satu faktor untuk membangkitkan motivasi belajar siswa, menghasilkan suasana belajar yang lebih rileks, menyenangkan dan pastinya tidak membosankan.

\section{Saran}

Berdasarkan hasil penelitian dan pembahasan yang telah dipaparkan diatas maka dalam kesempatan ini penulis menyampaikan beberapa saran sebagi berikut:

1. Bagi Guru

Guru hendaknya membust permainan ice breaking yang lebih kreatif dan inovatif agar pembelajaran lebih menarik dan tidak ada salahnya jika penggunaan ice breaking terutama untuk guru yang kurang bisa menciptakan suasana belajar yang menyenangkan karena dari ice breaking ini bisa memecahkan kebekuan atau menciptakan suasana belajar yang lebih rileks, menyenangkan, dan tidak mengurangi dari tujuan atau penyampaian pembelajaran itu sendri.

\section{Bagi Sekolah}

Pembelajaran dengan permainan ice breaking hendaknya dapat digunakan guru sebagai alternatif untuk menciptakan suasana belajar yang aktif, menyenangkan, tidak membosankan dan dapat meningkatkan motivasi belajar siswa.

\section{DAFTAR PUSTAKA}

Adi W. Gunawan. (2007). Genius Learning Strategy,

Jakarta: PT. Gramedia Pustaka Utama

Hamzah B. Uno. (2006). Teori Motivasi Dan

Pengukurannya. Jakarta: Bumi Aksara

Sunarto. (2012). Ice Breaking dalam Pembelajaran

Aktif. Surakarta: Cakrawala Media
Arikunto, Suharsimi. (2010) Prosedur Penelitian :

Suatu Pendekatan Praktik, Jakarta: Rineka

Cipta

Sugiyono. (2015). Metode penelitian pendidikan:

pendekatan kuantitatif, kualitatif dan $R \& D$.

Bandung: Alfabeta

Budiman , A. (2016). Panduan Menjadi MC Humoris

Yang Memukau dan Menghibur Audience.

Yogyakarta: Araska 